\title{
High output heart failure: A review of clinical status - epidemiology, pathophysiology, diagnosis, prognosis and clinical management
}

\author{
Aref Albakri* \\ St-Marien hospital Bonn Venusberg, Department of Internal Medicine, Bonn, Germany
}

\begin{abstract}
The clinical syndrome of heart failure (HF) has traditionally been associated with low or normal cardiac output accompanied by increased systemic vascular resistance. This association has led to the present under-appreciation of a minority group of HF patients presenting with high cardiac output but with normal cardiac function, clinically termed high-output HF. In these patients, the pathophysiological hallmark is decreased systemic vascular resistance. Because these patients lack proven therapies, treatment relies on evidence-based therapies developed for low-cardiac output HF. With a paucity of clinical trial data, evidence based from case reports suggest some of the established HF medications such as vasodilators and inotropes can be potentially detrimental for patients with high-output HF. These findings demonstrates an unmet clinical need for in-depth understanding of the pathophysiology, aetiology and clinical course of high-output HF, which forms the basis for the present review.
\end{abstract}

\begin{abstract}
Abbreviations: ACEI: Angiotensin Converting Enzyme Inhibitors; ADH: Antidiuretic Hormone; ARBs: Angiotensin Receptor Blockers; AVF: Arteriovenous Fistula; BMI: Body Mass Index; CAD: Coronary Artery Disease; CHF: Congestive Heart Failure; CLD: Chronic Lung Disease; HF: Heart Failure; HHT: Hereditary Haemorrhagic Telangiectasia; HHT: Hereditary Haemorrhagic Telangiectasia; IL: Interleukin; LV: Left Ventricular; LVEF: Left Ventricular Ejection Fraction; RAAS: Renin-Angiotensin-Aldosterone System; RV: Right Ventricular; $\mathrm{S}_{\mathrm{v}} \mathrm{O}_{2}$ : Mixed Venous Oxygen Saturation; TNF: Tumour Necrosis Factor.
\end{abstract}

\section{Introduction}

Heart failure (HF) describes a progressive clinical syndrome with complex and variable symptoms and signs including dyspnoea, tachypnoea, tachycardia, exercise intolerance, pulmonary rales and peripheral oedema [1]. Majorities of HF patients are classified as systolic and/or diastolic dysfunction with low or normal cardiac output accompanied by an elevated systemic vascular resistance [2]. However, in a minority of patients, it may occur in a number of high-output states, when cardiac output is greater than normal, referred to as high-output HF. These patients have normal cardiac function and decreased vascular resistance and despite their hyperdynamic state, the heart is unable to meet the body's demand for perfusion [3]. There is a notable lack of clinical trial data for management for high-output HF, with current evidence based on case series and reports. Moreover, in the absence of a correctable cause, therapeutic options are limited. However, with a high mortality rate, and increasing prevalence of obesity, liver and kidney diseases, which are the leading aetiologies of high-output HF [3-5], understanding its pathophysiology, diagnosis and clinical management has become very important. Similarly, it is the intention of this paper to present a review of published evidence on high-output HF to improve the understanding of its clinical status.

\section{Definition}

Generally, HF describes a clinical syndrome characterized by structural and/or functional defects in the myocardium leading to impaired ventricular filling or ejection of blood [1]. Although the predominant clinical manifestation of HF is low-cardiac output, the syndrome occurs in a minority of patients with high output states, defined as a resting cardiac output $>8 \mathrm{~L} / \mathrm{min}$ or a cardiac index $>3.9 /$ $\mathrm{min} / \mathrm{m}^{2}[4]$. In these patients, despite their hyperdynamic state, highoutput HF occurs when cardiac output is insufficient to meet the body's demand for perfusion accompanied by signs and symptoms of HF [3]. However, consensus on whether high-output HF is a distinct clinical entity or form of HF remains debatable. Some authors suggest the term "high-output HF" is a misnomer as cardiac function is intrinsically normal and capable of generating high cardiac output [4] while others suggest high-output HF is not a distinct form of HF since it develops only in the setting of an underlying systemic disease capable of causing high-output state [3-5]. Despite the lack of consensus, there is welldocumented evidence of HF in patients with chronic high-output states and excessively depressed systemic vascular resistance.

\section{Epidemiology}

The epidemiological burden of HF is well-established. It is a global epidemic and a major clinical and public health problem with significant mortality, morbidity and healthcare expenditures [6]. It has

${ }^{\star}$ Correspondence to: Aref Albakri, St-Marien hospital Bonn Venusberg, Department of Internal Medicine, Bonn, Germany, E-mail: arefalbakri@yahoo.com

Key words: high-output heart failure, low systemic vascular resistance

Received: June 04, 2019; Accepted: June 19, 2019; Published: June 22, 2019 
a prevalence of 5.8 million in the United States [7], 10 million in Europe [8] and over 23 million worldwide [6]. These statistics include all forms of HF (both low- and high-output HF). However, the exact incidence and prevalence rates of isolated high-output HF, a far less common form of HF, remains largely unknown. Some of the reasons for the lack of exact epidemiological data include a debate on whether it is a distinct clinical entity, it occurs secondary to underlying cardiac and extra-cardiac pathologies, it lacks precise guidelines for diagnosis, and its prevalence or incidence may be related to the underlying pathologies responsible causing high-output state [3,9].

\section{Aetiology}

A broad spectrum of congenital and iatrogenic conditions can cause high-output state and lead to the clinical syndrome of HF. In a Mayo clinical series of 120 patients diagnosed with high-output HF, the most common causes included obesity (31\%), liver disease $(23 \%)$, arteriovenous shunts (23\%), lung disease (16\%) and myeloproliferative disorders (8\%) [10]. However, the study used a select cohort (excluded patients with high-output state related to anaemia and hyperthyroidism) that under-presented many of the classical aetiologies of high-output HF that do not require invasive assessment. Nevertheless, the study provided valuable insights into shared pathologic mechanisms, which can be classified into two categories: vasodilation and arteriovenous shunting mechanisms [3,9]. These two categories are rarely exclusive, with many diseases exhibiting a combination of the two. In many cases, high-output state begins as adaptive physiological adjustments, and when the adjustments persist, lead to impaired cardiac function [10]. Table 1 provides a summary of the most common causes of highoutput HF classified under vasodilation and arteriovenous shunting aetiologies.

\section{Vasodilation conditions}

Vasodilation aetiologies lead to high-output HF via the relaxation of muscle cells within the walls of blood vessels causing them to dilate, reduce resistance to blood flow and ultimately increase blood flow volume $[3,5,9]$. Vasodilation is a consequence of an increase in the body's demand for perfusion because of increased metabolism [3]. Vasodilation aetiologies can be further characterized into metabolic, myocardial and other conditions.

\section{Metabolic diseases}

Metabolic diseases such as hyperthyroidism and myeloproliferative disorders can cause an increase in the body's metabolic demand in turn leading to high cardiac output state [3]. Hyperthyroidism is characterized by increased activation of the thyroid gland causing excessive secretion of thyroid hormones, which in turn affects both cardiac and systemic tissues [11-15]. Cardiac effects lead to

Table 1. Common causes of high-output heart failure

\begin{tabular}{|c|c|}
\hline Vasodilation & Arteriovenous Shunting \\
\hline 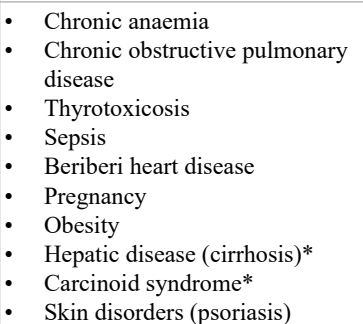 & 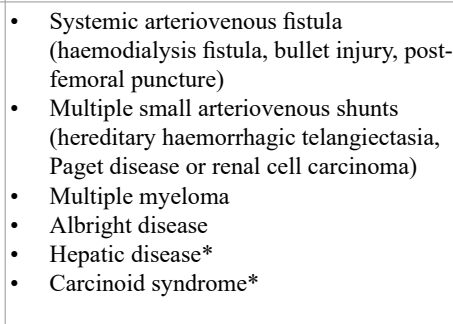 \\
\hline
\end{tabular}

* Share vasodilation and arteriovenous shunting categories (Adapted from Dharmendra et al., p. 502) hypercontractility and increased heart rate, while increased systemic metabolism leads to increased cellular waste products and decreased systemic vascular resistance. If left untreated, hypercontractility, tachycardia and volume overload can potentially lead to cardiac pathologies such as hypertrophy, cardiomyopathy and ultimately HF. Myeloproliferative disorders (increased production of abnormal red/ white blood cells or platelets) on the other hand, if left untreated can lead to increased cellular metabolism and high cell turnover resulting into a state of increased metabolic demands and low systemic vascular resistance [11-15].

\section{Myocardial diseases}

Myocardial diseases such as sepsis, cardiac beriberi and chronic lung disease that have a direct pathologic effect on the myocardium can lead to increased cardiac output. Severe sepsis is associated with an increase in the release of a number of vasoactive cytokines such as tumour necrosis factor (TNF)-alpha, interleukin (IL-1, IL-6), inducible nitric oxide synthase and other pro-inflammatory cytokines, which can lead to significant systemic vasodilation resulting in arterial hypotension and high-output HF [16-18]. Cardiac beriberi leads to high-output HF along with oedema, fatigue and general malaise [9]. It is common in patients diagnosed with long-term (> 3 months) deficiency of the $\mathrm{B} 1$ vitamin thiamine, enlarged heart with normal sinus rhythm, dependent oedema, signs of neuritis and pellagra, minor electrocardiographic (ECG) abnormalities and no other identifiable causes of HF and response to thiamine therapy [3,5]. High-output HF occurs in cardiac beriberi due to arteriolar and cutaneous vasodilatation leading to a reduced systemic vascular resistance $[19,20]$. Chronic lung disease (CLD) causes high-output HF, predominantly right-sided HF. Chronic hypoxia and hypercapnia result in low systemic arterial resistance leading to chronic volume overload, whereas pulmonary vascular constriction leads to increased right-heart remodelling while the left heart remain largely functional producing high cardiac output [3].

\section{Other diseases}

Other common conditions causing high-output state through vasodilatory effects include chronic severe anaemia and obesity [3-5]. Chronic severe anaemia results in several physiological adjustments to maintain both tissue perfusion and oxygenation. Peripheral vasodilation and high cardiac output cause an increase in tissue perfusion while systemic low blood viscosity and enhanced basal activity of nitric oxide due to upregulation of renal and vascular nitric oxide synthase cause a reduction in vascular resistance [21-23]. Low systemic vascular resistance causes neurohormonal activation leading to increased salt and water retention and blood volume expansion followed by pulmonary and systemic venous congestion ultimately leading to high-output HF $[4,5]$. Morbid obesity produces an increase in overall blood volume and cardiac output due to increased metabolic activity of excessive adipose tissue leading to altered left ventricular (LV) remodelling and high-output HF [24-27]. Several other less common clinical conditions such as pregnancy, hepatic disease, cirrhosis, and carcinoid syndrome can cause high-output HF through the common mechanisms of vasodilation and a fall in blood pressure $[3,5,9]$.

\section{Arteriovenous shunting}

Arteriovenous shunting describes a condition characterized by the bypass of arteriolar and capillary bed resulting into increased venous circulation due to the lack of resistance leading to increased oxygen consumption and low systemic vascular resistance [3,9]. Resistance 
occurs in the arteriolar system because of a collective decrease in arterioles radius and flow into the venous circulation. Bypassing the arteriolar system increases flow to the venous circulation causing an increased venous return to the heart ultimately leading to cardiac volume overload [3]. Common conditions leading to arteriovenous shunting include systemic arteriovenous fistula, multiple small arteriovenous shunts and multiple myeloma [5].

\section{Arteriovenous fistula}

Systemic arteriovenous fistula (AVF), either congenital or acquired, is a rare clinical entity characterized by a shunt from an artery to a vein, which bypasses the resistance of the arteriolar and capillary systems to increase venous return to the heart. The increased venous flow causes an increase in heart rate and stroke volume leading to increased cardiac output. Congenital AVF usually involves the formation of large or several haemangiomas/telangiectasia while acquired AVF usually involves traumatic, iatrogenic formation or development of skeletal disorders causing several small AVF formations [3]. The presence of AVF during pregnancy can contribute to pre-existing high-output state and even HF. In early infancy, hepatic haemangiomas/haemangioendotheliomas result in hemodynamically significant arteriovenous shunting of blood with resultant fluid retention while in adulthood, Osler-Weber-Rendu disease can manifest with intrahepatic AVF and resultant hyperdynamic state, fluid retention and pulmonary hypertension [5].

\section{Skeletal disorders}

Skeletal disorders such as Paget disease, Albright syndrome and multiple myeloma can cause high-output HF because of the lowering of the systemic vascular resistance and a compensatory rise in cardiac output $[28,29]$. The rise in cardiac output is due to the presence of multiple minute AVF in the bony (skeletal) lesions. Paget's disease has been associated with rapid bone formation and resorption leading to increased blood flow within the bone and the surrounding limb tissue [30]. Significant skeletal involvement (>15\%) is required to cause shunting and low peripheral vascular resistance, which may lead to high-output HF [31,32]. Both multiple myeloma and Albright syndrome (fibrous dysplasia) through a similar mechanism have been associated with arteriovenous shunting and high-output HF [33,34]. Co-occurring anaemia can exacerbate high-output $\mathrm{HF}$ in patients with skeletal disorders [5].

\section{Pathophysiology}

The pathophysiology of high-output cardiac state and the associated clinical HF with or without the presence of underlying heart disease is largely unique to the underlying aetiology [5]. However, reduced systemic vascular resistance due to arteriovenous shunting or peripheral vasodilation or both is the hallmark of physiological dysregulation in patients with high-output HF (Figure 1). The two mechanisms lead to a fall in systemic arterial blood pressure (a feature of low-output $\mathrm{HF}$ ) in turn causing sympathetic neural activation, a compensatory increase in cardiac output and neurohormonal activation including the renin-angiotensin-aldosterone system (RAAS), adrenergic system and excessive antidiuretic hormone (ADH) [35,36]. These compensatory mechanisms lead to salt and water retention and overt clinical HF, which occurs in both low- and high-output HF $[4,36]$. The activation of RAAS increases intravascular blood volume in the acute and sub-

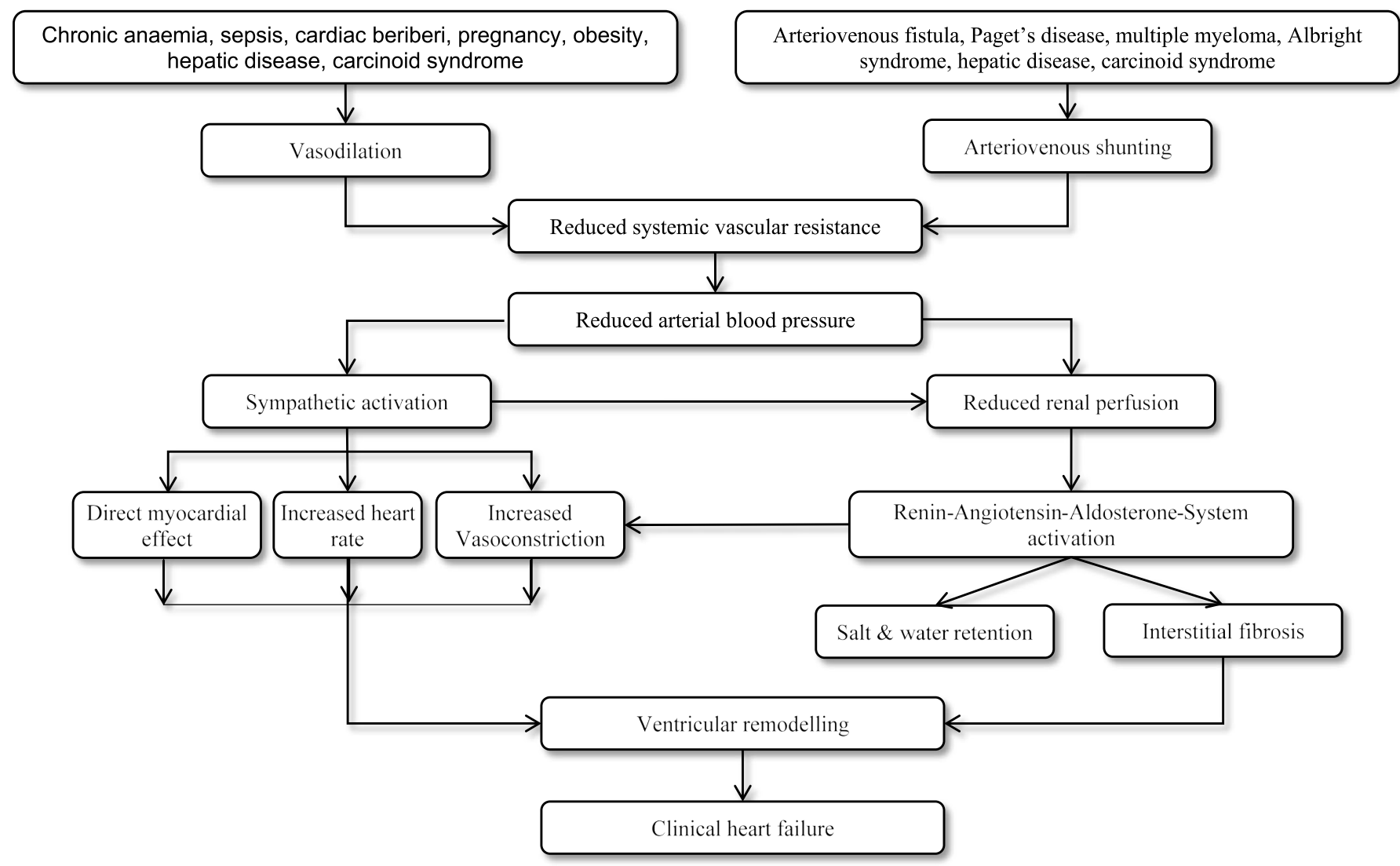

Figure 1. Pathophysiology of high-output heart failure (Adapted from Mehta and Dubrey 2009, p. 236 [5]) 
acute settings but chronic activations can result into a progressive decline in cardiac function. In compensating for the hemodynamic burden (increased venous return), the heart undergoes hypertrophy and remodelling to preserve contractility, and dilatation to reduce wall stress. Over time, the dilatation exceeds and holds more blood volume than the heart can effectively pump, leading to HF [5].

The goal of the adrenergic system is to increase cardiac output (which in high-output state is already elevated) by increasing contractility (stroke volume) and heart rate while preserving systemic blood pressure through vasoconstriction. Increased renin in response to decreased renal artery perfusion and the adrenergic nervous system activates the RAAS [37]. The secretion of renin leads to increased circulating angiotensin II resulting in an increase in aldosterone secretion from adrenal cortex and stimulating thirst in the hypothalamus. Aldosterone increases sodium reabsorption resulting in increased water retention at the kidney level aimed to increase intravascular volume and thereby augmenting preload [3,5]. A rise in preload allows for increased cardiac output through the Frank-Starling mechanism but in an already weak heart, this mechanism does not augment cardiac output but causes excessive hypervolemia, resulting in peripheral oedema and pulmonary congestion evident in clinical HF. On the other hand, $\mathrm{ADH}$ is activated in response to angiotensin II and baroreceptors to cause an increase in water retention at the kidney level. $\mathrm{ADH}$ can contribute to vasoconstriction as well [3] (Figure 1).

\section{Diagnosis}

Definitive diagnosis of high-output HF continues to be an important clinical challenge. Although several international consensus guidelines have been published to date for the diagnosis and treatment of HF $[8,38,39]$, they are specific to low-output HF with no or only a vague reference to high-output HF. Moreover, high-output HF often occurs in the presence of underlying cardiac or extra-cardiac pathologies $[9,10]$, which complicate the development a common diagnostic algorithm. In addition to diagnosis, the identification of the specific aetiology of high output state is important for several reasons. Many of the aetiologies are curable or may cause fluid retention, a condition refractory to conventional HF therapy, which can potentially aggravate the preexisting disease [4]. Since reduced peripheral vascular resistance is the hallmark pathologic mechanism in high-output HF, the use of vasodilator therapy indicated for the treatment of congestive HF may further reduce vascular resistance [37].

The initial steps in the diagnosis of high-output HF is based on physical examination and patient history, which inform which further tests to be undertaken. Additional diagnostic cues are obtained from laboratory testing and cardiac imaging (usually chest radiography and echocardiography) [5]. Laboratory tests such as the assessment of serum levels of natriuretic peptides (NPs) is also highly beneficial when the diagnosis of $\mathrm{HF}$ is unclear, in which elevated levels strongly suggest HF. Cardiac imaging is useful to visualize and characterise abnormalities in cardiac function and/or structure [38,39]. In contrast to low-output HF, patients with high-output HF have the presence of a high cardiac output and/or cardiac index [5,9]. The detection of clinical HF in the setting of high-output state confirm the diagnosis of high-output HF.

\section{History and physical examination}

A thorough history and physical examination is very important in the initial evaluation of high-output HF. Assessment of a patient's history about previous chronic medical conditions can facilitate the determination of underlying aetiology of high-output HF. Same to patients with low-output HF, those with high-output HF usually present with complaints of progressively worsening dyspnoea either at rest or on exertion, exercise intolerance, fatigue and fluid retention [40]. Some may present with complaints of palpitations or heart racing. On physical examination, tachycardia, tachypnoea, elevated jugular venous pressure, pulmonary rales, pleural effusion and pulmonary or peripheral oedema may be present [39]. Contrasted to low-output HF, features raising clinical suspicion and/or diagnosis of high-output HF include warm peripheries, preserved LV function ( $>45-50 \%)$, cardiac output $>8 \mathrm{~L} / \mathrm{min}$, mixed venous oxygen saturation $\left(\mathrm{S}_{\mathrm{v}} \mathrm{O}_{2}\right)>70-75 \%$ and aetiology consistent with high cardiac output-state (Table 2) [5].

Physical signs can also be useful in the diagnosis of the underlying aetiology of high-output state. Cardiac symptoms of high-output HF can be secondary or incidental in patients who initially present with symptoms of the underlying disease. Hyperthyroidism presents with a wide range of cardiac symptoms such as tachycardia, palpitations and dyspnoea as well as physical signs such as fever, eyelid retraction, lid lag, tremor, hyperreflexia, hyperactivity and enlarged thyroid gland [11-15]. The common physical signs in myeloproliferative disorders include fever, fatigue, dyspnoea, increased bleeding periods and signs of splenomegaly [4]. Patients with sepsis may present with fever, chills, fatigue, loss of appetite, palpitations, and altered mental state. On physical examination, patients with sepsis can show fever, tachycardia, tachypnoea and warm peripheries while advanced stages show worsening myocardial dysfunction, LV failure and ultimately systolic HF [16-18]. Cardiac beriberi can present with a history of malnourished, alcoholic, dieting or bariatric patient. On physical examination, beriberi patients often complain of dyspnoea, orthopnoea, palpitations and peripheral oedema as well as burning pain on peripheries and muscle weakness [5,9]. Patients with congenital AVF may present with hereditary haemorrhagic telangiectasia (early infancy) or Osler-Weber-Rendu syndrome (in adulthood) with mucocutaneous or gastrointestinal bleeding episodes while those with acquired AVF (iatrogenic or traumatic) present with progressive dyspnoea, orthopnoea and oedema as well as palpable thrills and audible bruits over the AVF itself [9]. Patients with liver cirrhosis usually have a history of causes such as alcohol abuse, viral hepatitis, obesity and autoimmune diseases and the presenting symptoms include fatigue, general weaknesses, increased swelling, dyspnoea, abdominal distension, yellowing of skin and eyes and gastrointestinal haemorrhaging $[3,9]$. Finally, morbid obese patients have a high body mass index (BMI) $\geq 30 \mathrm{~kg} / \mathrm{m}^{2}$ and on physical examination can present with signs of clinical HF with tachycardia $[4,9]$. Table 3 provides a summary of cardiac and extra-cardiac physical signs (Table 3).

\section{Non-invasive cardiac Imaging}

Current consensus guidelines on diagnosing of HF recommend cardiac imaging to assess abnormalities in cardiac function and structure $[38,39]$. Chest radiography is essential in the clinical evaluation of $\mathrm{HF}$ for the assessment of cardiomegaly, pulmonary congestion and pleural

Table 2. Differences between signs and symptoms of low- and high-output HF

\begin{tabular}{|c|c|c|}
\hline Signs or symptoms & $\begin{array}{c}\text { Suspicion for high-output } \\
\text { HF }\end{array}$ & $\begin{array}{c}\text { Suspicion for low-output } \\
\text { HF }\end{array}$ \\
\hline Peripheries & Warm & Cold \\
\hline LV function & Preserved & Systolic dysfunction \\
\hline Cardiac output & $>8 \mathrm{~L} / \mathrm{min}$ & $<4 \mathrm{~L} / \mathrm{min}$ \\
\hline $\begin{array}{c}\text { Mixed venous oxygen } \\
\text { saturation }\left(\mathrm{S}_{\mathrm{v}} \mathrm{O}_{2}\right)\end{array}$ & $>70-75 \%$ & $<65 \%$ \\
\hline Aetiology consistent with & High-output state & Low-output state \\
\hline
\end{tabular}

Adapted from Mehta and Dubrey 2009, p. 237 [5] 
Table 3. Physical signs related to underlying disease causing high-output state

\begin{tabular}{|l|l|l|}
\hline Underlying Disease & Cardiac Symptoms & Physical Signs \\
\hline Hyperthyroidism & Tachycardia, palpitations and dyspnoea & $\begin{array}{l}\text { Fever, eyelid retraction, lid lag, tremor, hyperreflexia, hyperactivity and enlarged thyroid } \\
\text { gland }\end{array}$ \\
\hline Myeloproliferative disorders & Fatigue, dyspnoea & $\begin{array}{l}\text { Fever, increased bleeding periods, signs of splenomegaly and peripheral blood smear } \\
\text { abnormality }\end{array}$ \\
\hline Sepsis & Tachycardia, tachypnoea and warm peripheries & Fever, chills, fatigue, loss of appetite, palpitations, and altered mental state \\
\hline Cardiac Beriberi & Dyspnoea, orthopnoea, palpitations and peripheral oedema. & $\begin{array}{l}\text { A history of malnourished, alcoholic, dieting or bariatric patient as well as burning pain } \\
\text { on peripheries and muscle weakness }\end{array}$ \\
\hline Arteriovenous Fistula & $\begin{array}{l}\text { Dyspnoea, orthopnoea and oedema as well as palpable thrills } \\
\text { and audible bruits over the AVF itself }\end{array}$ & $\begin{array}{l}\text { Hereditary haemorrhagic telangiectasia or Osler-Weber-Rendu syndrome with } \\
\text { mucocutaneous or gastrointestinal bleeding episodes }\end{array}$ \\
\hline Liver cirrhosis & $\begin{array}{l}\text { Fatigue, general weaknesses, increased swelling, and } \\
\text { dyspnoea. }\end{array}$ & $\begin{array}{l}\text { A history of alcohol abuse, viral hepatitis, obesity and autoimmune diseases. Abdominal } \\
\text { distension, yellowing of skin and eyes and gastrointestinal haemorrhaging }\end{array}$ \\
\hline Obesity & Signs of clinical heart failure with tachycardia & High body mass index (BMI) $\geq 30 \mathrm{~kg} / \mathrm{m}^{2}$. \\
\hline
\end{tabular}

fluid accumulation [41]. The findings of pulmonary disease and sepsis in the setting of pneumonia is relevant in diagnosing high-output HF [16-18]. Echocardiography is mandatory in patients with suspected HF. In high-output HF, echocardiography is useful to demonstrate normal cardiac function defined as LV ejection fraction [LVEF] $>45$ $50 \%[2,38,39]$ since high-output HF can occur despite preserved LV systolic function. Patients can subsequently develop compensatory LV dilatation with or without hypertrophy with deleterious consequences of a worsening HF [5].

\section{Invasive hemodynamic assessment}

The assessment of venous blood gas by invasive hemodynamic measurement in HF patients is often necessary when direct measurement methods such as Fick method (oxygen consumption/ arterial-venous oxygen difference) or thermodilution to confirm highoutput state is not readily available [10]. The assessment of mixed venous oxygen saturation $\left(\mathrm{S}_{\mathrm{v}} \mathrm{O}_{2}\right)$ provides an estimation of the body's oxygen consumption/delivery ratio and an approximation of cardiac output. $\mathrm{S}_{\mathrm{v}} \mathrm{O}_{2}>65 \%$ is associated with low cardiac output while high $\mathrm{S}_{\mathrm{v}} \mathrm{O}_{2}$ $>75 \%$ suggests high cardiac output [5].

\section{Prognosis}

Although prognostication of patients with high-output HF is not well understood, Reddy et al prospective study on the aetiologies of $\mathrm{HF}$ associates the underlying aetiology and degree of vasodilation to poor prognosis [10]. In the study, patients with high-output HF had an increased 3-year mortality rate compared to healthy controls (hazard ratio [HR]: 3.4; 95\% CI: 1.6-7.6; $\mathrm{p}=0.002$ ). Mortality rate differed based on the underlying aetiology. The lowest 5-year mortality rate was associated with obesity (19\%), and the highest mortality rates with liver disease (58\%) and $\mathrm{HF}$ associated with shunt formation (59\%). Excessive vasodilation irrespective of the underlying aetiology was associated with an ominous prognosis. Mortality was higher in $61 \%$ patients with a very low vascular resistance $\left(1,030\right.$ dyne $/ \mathrm{m}^{2}$ per $\left.\mathrm{s} / \mathrm{cm}^{5}\right)(61 \%)$ compared to $36 \%$ of patients with mildly depressed or normal systemic vascular resistance (HR: 2.5; 95\% CI; 1.2-5.1; $\mathrm{p}=0.01$ ).

\section{Clinical management}

\section{Therapy for heart failure}

Medical therapy remains the primary treatment for patients with HF but most medications are either contra-indicated or not advisable for patients with high output HF. The reasons is that, although in both low- and high-output HF the final pathogenesis is salt and water retention, they differ in the degree of systemic vascular resistance $[5,9]$. Low-output HF has normal to high systemic vascular resistance with high circulating vasoconstrictors and recommended treatment is neurohormonal antagonists such as angiotensin converting enzyme inhibitors (ACEI), angiotensin receptor blockers (ARBs), aldosterone antagonists and beta-blockers, which have been documented to improve mortality and morbidity [39]. On the other hand, in highoutput HF patients have low systemic vascular resistance and the use of established vasodilator therapies such as ACEI, ARBs and newer betablockers with vasodilatory properties such as carvedilol and nebivolol are contra-indicated because they can aggravate the condition. The use of beta-adrenoreceptor positive inotropes is also not advisable in patients with high-output HF [38].

Although treatment options are limited for high-output HF, there are some supportive therapies such as dietary restriction of salt and water, and judicious use of diuretics. Clinical management usually begins with acute intervention of HF. Based on the severity, medical management should target acute respiratory failure from volume overload and hypotension if present. Initial medication can range from intermittent diuretic therapy and oxygen supplementation to continuous diuretic infusion, non-invasive positive pressure ventilation or intubation. Respiratory intervention using high ventilator peak endexpiratory pressure for resistant pulmonary oedema may be useful [5]. If hypotension and decreased organ perfusion are present, inotropic drugs can be indicated. A number of intravenous vasoconstrictor adrenergic drugs are available including noradrenaline, ephedrine, metaraminol and phenylephrine. These drugs increase systemic vascular resistance by acting on the alpha-adrenergic receptors to constrict peripheral blood vessels. However, such drugs are useful for short-term adjuncts in acute settings while the treatment for the underlying aetiology is ongoing. Long-term use of these drugs is not recommended because they can lead to a reduction in vital organ perfusion and tachycardia due to beta-adrenergic receptor activation such as ephedrine [5].

\section{Therapy for underlying conditions}

In patients who have been stabilized by HF medication and who are no longer in a decompensated state, management can then target the specific underlying aetiology to correct the cause of low systemic vascular resistance or can be administered alongside HF medication $[8,9]$. Treatment of hyperthyroidism targets to reduce the levels of circulating thyroid hormones through medication, radiotherapy or surgery if necessary. For myeloproliferative diseases, treatment depends on the specific underlying disease and can involve hematopoietic cell transplantation based on the severity of symptoms [13-15]. Treatment for sepsis is based on recommendations of the Surviving Sepsis Campaign guidelines, which involves early recognition, immediate and aggressive intravenous fluid resuscitation and antibiotic therapy with an investigation to find the source of infection $[17,18]$. In patients with cardiac beriberi, thiamine deficiency is managed by thiamine 
replacement therapy for a minimum of two weeks [9]. For high-output state secondary to chronic lung disease, treatment targets the underlying pulmonary disease. For patients with hypoxia and hypercapnia, clinical management is symptomatic therapy targeting to slow the progression of the underlying disease [3]. Treatment for congenital AVF depends on the exact underlying cause and may include medical therapy, invasive embolization or surgical incision while treatment for acquired AVF is either closure or reduction of blood flow. End-stage liver cirrhosis that is sufficient to cause high-output HF is treated by liver transplantation $[3,9]$. Medical therapy using a dual therapy of loop diuretics and anti-mineralocorticoids for fluid management for patients with hypervolemia to limit flow through shunts [39].

\section{A review of case reports on high-output HF}

Definitive diagnosis and treatment of high-output HF remains an important clinical challenge because of its very heterogeneous aetiologies as well as the lack of international consensus guidelines and clinical trial data to support diagnosis. To date, the Reddy et al. [10] retrospective analysis of all consecutive patients referred to the Mayo Clinic catheterization laboratory for hemodynamic assessment between 2000 and 2014 remains the only frequently referenced long-term trial (15 years) that specifically investigated aetiologies, pathophysiology, clinical and hemodynamic characteristics, and outcomes of patients with high-output HF. Other studies such as Dupuis-Girod et al. [42] investigate treatment of the underlying cause of high-output HF with only a brief mention of treatment effect on cardiac performance. As a result, current evidence on the diagnosis and treatment of high output HF largely relies on case reports and expert opinions.

The challenge in case reports is uncontrolled study designs known for increased risk of bias as well as weak inferences resulting in minimal attention devoted to developing frameworks to appraise, synthesize and apply their evidence in clinical decision-making [43]. Moreover, since evidence-based medicine (EBM) involves finding and using evidence to make clinical decisions, whose cornerstone is a hierarchical system of classifying evidence, case reports are at the lowest levels of the hierarchy [44]. Nevertheless, case reports have profoundly influenced medical literature and have continued to advance clinical knowledge in the present time. In particular, systematic reviews of case reports have provided observations important for learning through pattern recognition, which is integral to advance medical knowledge $[45,46]$. Furthermore, case reports have also been used on quantitative synthesis to provide estimates of prevalence or event rates in the form of proportion pooled using fixed or random effect models [47] but cannot produce relative association measures such as odds ratio or relative risk [43].

With lack of clinical trial data, the present article provides a systematic review of available published case reports investigating patients with high-output HF to determine aetiologies, diagnosis and treatment. However, because of high heterogeneity of underlying aetiologies, it was not possible to calculate pooled proportion of effect sizes on cardiac output or systemic vascular resistance.

\section{Methods}

\section{Search strategy}

Online databases PubMed, Medline, EMBASE, Web of Science and the Cochrane Library were searched through December 2018 without restrictions. Case reports investigating diagnosis and treatment of highoutput HF were included. The key words used in the search were "high output cardiac failure" OR "high-output heart failure" AND underlying aetiologies (arteriovenous fistula, hyperthyroidism, pregnancy hepatic disease, obesity) AND "diagnosis" or "treatment" AND "case reports". Case reports were included if they investigated patients diagnosed with high-output heart failure, provided diagnosis procedure and tests, treatment and pre- and post-outcome measures of treatment on cardiac symptoms and function. There was no restriction on publication date or language.

\section{Data extraction and analysis}

The initial screening of retrieved publications was reviewing titles and abstracts independently by two reviewers followed by full-text review against the inclusion criteria. Any discrepancy was resolved through discussion. For case reports meeting the inclusion criteria and included in this systematic review, the following information was collected: first author, publication year, age and sex of patients, presenting physical and cardiac signs and symptoms, treatment used, follow-up period and post-treatment outcomes on cardiac symptoms and function. Narrative and descriptive statistics were used to discuss specific findings from the included studies.

\section{Quality assessment}

Two investigators independently performed a quality assessment of the selected case reports and differences in scoring were resolved through discussion and consensus. The evaluation criteria for the quality appraisal of case reports used the tool for evaluating the methodological quality of case reports and case series developed by the Murad et al. (Table 4) [43]. We summarized the result of this tool by summing the score of the eight binary responses into an aggregate score.

\section{Results}

\section{Study characteristics}

Twenty-one (21) publications [48-68] met the inclusion criteria and were included for systematic analysis. A summary of the case details are presented in Table 5. They reported 23 cases of high-output HF consisting of 13 male and 11 female patients. The cases included patients from all ages, ranging from as young as a 2-day premature infant [67] to older adults (84 years) [68]. The follow-up periods widely varied from a few days ( 2 days) to months (11 months). In all the cases, there was consensus that the clinical syndrome of highoutput HF develops only in the setting of systemic diseases that cause arteriovenous shunting or vasodilation. Systemic AVF as an underlying aetiology of high-output HF was investigated in a majority of studies, mostly post-traumatic AVF following surgical intervention such as

Table 4. Elements evaluated in quality assessment

\begin{tabular}{|c|c|}
\hline Domain & Leading explanatory question \\
\hline Selection & $\begin{array}{l}\text { 1. Does the patient(s) represent(s) the whole experience of the } \\
\text { investigator (centre) or is the selection method unclear to the extent } \\
\text { that other patients with similar presentation may not have been } \\
\text { reported? }\end{array}$ \\
\hline Ascertainment & $\begin{array}{l}\text { 2. Was the exposure adequately ascertained? } \\
\text { 3. Was the outcome adequately ascertained? }\end{array}$ \\
\hline Causality & $\begin{array}{l}\text { 4. Were other alternative causes that may explain the observation ruled } \\
\text { out? } \\
\text { 5. Was there a challenge/rechallenge phenomenon? } \\
\text { 6. Was there a dose-response effect? } \\
\text { 7. Was follow-up long enough for outcomes to occur? }\end{array}$ \\
\hline Reporting & $\begin{array}{l}\text { 8. Is the case(s) described with sufficient detailed to allow other } \\
\text { investigators to replicate the research or allow practitioners make } \\
\text { inferences related to their own practice? }\end{array}$ \\
\hline
\end{tabular}

Adapted from Murad et al. 201, p. 618 [43] 
Table 5. Summary of case series and reports on high-output heart failure

\begin{tabular}{|c|c|c|c|c|c|c|c|c|}
\hline 1st Author [Ref \#] & Year & Age & Sex & Aetiology & Signs \&Symptoms & Treatment & FuP & Outcomes \\
\hline Braverman et al. [48] & 1995 & 50 & M & Cirrhosis & $\begin{array}{c}\text { Pedal/pulmonary oedema, } \\
\text { oesophageal variceal bleeding, } \\
\text { abdominal swelling, dyspnoea, } \\
\text { cardiomegaly, bilateral pleural } \\
\text { effusions, interstitial pulmonary } \\
\text { oedema }\end{array}$ & Liver transplantation & 48 hours & $\begin{array}{l}\text { Improved cardiac index }(6.2 \\
\left.\text { to } 3.3 \mathrm{~L} / \mathrm{min} / \mathrm{m}^{2}\right) ; \text { cardiac } \\
\text { output }(12.8 \text { to } 6.9 \mathrm{~L} / \mathrm{min}) \text {; and } \\
\text { systemic vascular resistance } \\
\left(<300 \text { to } 850 \text { dyne } \mathrm{s} / \mathrm{cm}^{-5}\right)\end{array}$ \\
\hline Korn et al. [49] & 1998 & 29 & $\mathrm{~F}$ & $\begin{array}{c}\text { Pregnancy/Renal } \\
\text { AVF }\end{array}$ & $\begin{array}{c}\text { Dyspnoea, orthopnoea, } \\
\text { paroxysmal nocturnal dyspnoea, } \\
\text { and bilateral, pedal oedema, } \\
\text { jugular venous distention, } \\
\text { accentuated first and second } \\
\text { heart sounds, a third heart sound, } \\
\text { pulmonary rales }\end{array}$ & $\begin{array}{l}\text { Nephrectomy (surgical } \\
\text { removal of AVF) }\end{array}$ & 3 months & $\begin{array}{c}\text { Initial cardiac index of } 8.7 \mathrm{~L} / \\
\mathrm{min} / \mathrm{m}^{2} \text {. Resolution of symptoms } \\
\text { and healthy }\end{array}$ \\
\hline Manghat et al. [50] & 2003 & 61 & M & $\begin{array}{l}\text { Iatrogenic AVF } \\
\text { (after total knee } \\
\text { replacement) }\end{array}$ & $\begin{array}{l}\text { Sudden, severe shortness of } \\
\text { breath, atrial fibrillation, systolic } \\
\text { murmur, pulmonary oedema }\end{array}$ & Surgical repair of AVF & NA & Resolution of cardiac symptoms \\
\hline Ozaki et al. [51] & 2003 & 53 & $\mathrm{~F}$ & $\begin{array}{l}\text { Massive AVF } \\
\text { associated with } \\
\text { pelvic tumour }\end{array}$ & $\begin{array}{c}\text { Cardiomegaly and mild } \\
\text { pulmonary congestion, } \mathrm{LV} \\
\text { dilatation and hyperkinesis of the } \\
\text { LV wall motion }\end{array}$ & NA & NA & Cardiac output $13.2 \mathrm{~L} / \mathrm{min}$ \\
\hline Mitchell et al. [52] & 2008 & 47 & $\mathrm{~F}$ & $\begin{array}{l}\text { Congenital AVF } \\
\text { (HHT) }\end{array}$ & $\begin{array}{l}\text { Worsening high-output cardiac } \\
\text { failure, ascites, and bilateral } \\
\text { pleural effusions }\end{array}$ & $\begin{array}{l}\text { Anti-angiogenesis therapy } \\
\text { (Bevacizumab } 5 \mathrm{mg} / \mathrm{kg} \text { for } \\
12 \text { wks.) }\end{array}$ & 6 months & $\begin{array}{l}\text { All symptoms resolved, } \\
\text { Normalize cardiac output }(10.2 \\
\text { to } 5.1 \mathrm{~L} / \mathrm{min})\end{array}$ \\
\hline \multirow{2}{*}{ Robin et al. [53] } & \multirow{2}{*}{2008} & 50 & M & Multiple myeloma & $\begin{array}{c}\text { Pulmonary and lower extremities } \\
\text { oedema, dyspnoea, jugular } \\
\text { venous distension, tachycardia } \\
\text { mild cardiomegaly. }\end{array}$ & $\begin{array}{l}\text { Anti-angiogenesis therapy } \\
\text { (Bortezomib). Refractory to } \\
\text { anti-diuretic therapy }\end{array}$ & 35 days & $\begin{array}{c}\text { Symptom improvement, reduced } \\
\text { cardiac output } 15 \text { to } 10.6 \mathrm{~L} / \\
\text { min, died }\end{array}$ \\
\hline & & 61 & M & Multiple myeloma & $\begin{array}{c}\text { Fatigue and lower extremity } \\
\text { oedema, pulmonary crackles, } \\
\text { warm extremities, jugular venous } \\
\text { distension }\end{array}$ & $\begin{array}{l}\text { Anti-angiogenesis therapy } \\
\text { (Dexamethasone) and } \\
\text { Immunomodulatory drug } \\
\text { (lenalidomide/thalidomide) }\end{array}$ & 2 months & $\begin{array}{l}\text { Symptom improvement, reduced } \\
\text { cardiac output } 10 \text { to } 4.7 \mathrm{~L} / \mathrm{min}\end{array}$ \\
\hline Goussous et al. [54] & 2009 & 43 & M & Pregnancy & $\begin{array}{c}\text { Severe orthopnoea, nocturnal } \\
\text { paroxysmal dyspnoea, and lower } \\
\text { extremity oedema. }\end{array}$ & $\begin{array}{l}\text { Metoprolol, furosemide \& } \\
\text { spironolactone }\end{array}$ & 14 days & $\begin{array}{l}\text { Relief of abdominal pain and } \\
\text { resolution of lower extremity } \\
\text { oedema }\end{array}$ \\
\hline Khreiss et al. [55] & 2009 & 35 & $\mathrm{~F}$ & Hepatic disease & $\begin{array}{l}\text { Dyspnoea (at rest and with } \\
\text { exertion), orthopnoea, jugular } \\
\text { venous distension, bilateral } \\
\text { basilar crackles, peripheral } \\
\text { oedema involving both lower } \\
\text { extremities }\end{array}$ & $\begin{array}{l}\text { Surgical division of the } \\
\text { fistula }\end{array}$ & 1 month & $\begin{array}{l}\text { Cardiac output } 15.91 \mathrm{l} / \mathrm{min} \text {, } \\
\text { that dropped to } 8.61 \mathrm{l} / \mathrm{min} \text {, no } \\
\text { recurrence of symptoms }\end{array}$ \\
\hline Turgutalp et al. [56] & 2011 & 60 & $\mathrm{~F}$ & $\begin{array}{l}\text { Iatrogenic AVF - } \\
\text { hepatic disease, } \\
\text { treatment of } \\
\text { central venous } \\
\text { occlusion }\end{array}$ & $\begin{array}{l}\text { Left internal jugular venous } \\
\text { distention and severe swelling on } \\
\text { left arm, bilateral jugular venous } \\
\text { distention, pulmonary crackles, } \\
\text { tachycardia, pulmonary oedema }\end{array}$ & $\begin{array}{l}\text { Nasal oxygen, intravenous } \\
\text { loop diuretic, and } \\
\text { nitroglycerin and tourniquet }\end{array}$ & 3 months & $\begin{array}{l}\text { Initial cardiac index } 5.2 \mathrm{~L} / \mathrm{min} / \\
\mathrm{m}^{2} \text { remained asymptomatic at } \\
3 \text { months }\end{array}$ \\
\hline Chen et al. [57] & 2014 & 33 & M & $\begin{array}{l}\text { Renal AVF after } \\
\text { nephrectomy }\end{array}$ & $\begin{array}{c}\text { Exertional dyspnoea, chest } \\
\text { distress, and fatigue for } 1 \text { month }\end{array}$ & $\begin{array}{l}\text { Surgical: laparotomy to close } \\
\text { AVF }\end{array}$ & 11 months & $\begin{array}{c}\text { Full recovery, decrease in } \\
\text { cardiac index } 7.23 \text { to } 4.53 \mathrm{~L} / \\
\mathrm{min} / \mathrm{m}^{2}\end{array}$ \\
\hline Hayek et al. [58] & 2014 & 58 & M & Renal disease & $\begin{array}{l}\text { Hypervolemia with jugular } \\
\text { venous distention, diffuse } \\
\text { bilateral pulmonary crackles, } \\
\text { warm lower extremities with } \\
\text { bilateral pitting oedema }\end{array}$ & NA & NA & $\begin{array}{l}\text { Initial tests cardiac output } 15.2 \\
\mathrm{~L} / \mathrm{min} \text { and a cardiac index } 5.7 \\
\mathrm{~L} / \mathrm{min} / \mathrm{m}^{2}\end{array}$ \\
\hline \multirow[t]{2}{*}{ Khan et al. [59] } & 2013 & 35 & $\mathrm{~F}$ & $\begin{array}{l}\text { Hyperthyroidism } \\
\text { (Thyrotoxicosis) }\end{array}$ & $\begin{array}{l}\text { Breathlessness and palpitations } \\
\text { raised internal jugular venous } \\
\text { pressure and bilateral pitting } \\
\text { pedal oedema, gallop rhythm }\end{array}$ & Anti-thyroid drugs & 1 year & $\begin{array}{l}\text { Restoration of euthyroid levels, } \\
\text { symptomatic improvement but } \\
\text { no effect on cardiac output }\end{array}$ \\
\hline & & 65 & M & $\begin{array}{l}\text { Hyperthyroidism } \\
\text { (Thyrotoxicosis) }\end{array}$ & $\begin{array}{l}\text { Breathlessness, progressive } \\
\text { dyspnoea on exertion, } \\
\text { palpitation, cardiomegaly }\end{array}$ & Anti-thyroid drugs & 1 year & $\begin{array}{l}\text { Restoration of euthyroid levels, } \\
\text { symptomatic improvement but } \\
\text { no effect on cardiac output }\end{array}$ \\
\hline Rymer et al. [60] & 2013 & 54 & M & $\begin{array}{l}\text { Post-traumatic } \\
\text { AVF }\end{array}$ & $\begin{array}{c}\text { Bilateral lower extremity oedema } \\
\text { and dyspnoea on exertion, } \\
\text { palpable thrill over the right } \\
\text { base of the neck with a loud } \\
\text { continuous bruit, elevated jugular } \\
\text { venous distention }\end{array}$ & $\begin{array}{l}\text { Ligation and repair of the } \\
\text { fistula }\end{array}$ & NA & $\begin{array}{c}\text { Resolution of symptoms, cardiac } \\
\text { output } 12.8 \mathrm{~L} / \mathrm{min} \text {, cardiac index } \\
\text { of } 6.6 \mathrm{~L} / \mathrm{min} / \mathrm{m}^{2}\end{array}$ \\
\hline Singh et al. [61] & 2014 & 48 & $\mathrm{~F}$ & $\begin{array}{l}\text { Congenital AVF } \\
\text { (HHT) }\end{array}$ & $\begin{array}{c}\text { Worsening shortness of breath } \\
\text { and lower extremity oedema, } \\
\text { oropharyngeal bleeding, } \\
\text { aspiration of blood, cardiac arrest } \\
\text { and death }\end{array}$ & NA & NA & High cardiac output of $8.2 \mathrm{~L} / \mathrm{min}$ \\
\hline
\end{tabular}




\begin{tabular}{|c|c|c|c|c|c|c|c|c|}
\hline 1st Author [Ref \#] & Year & Age & Sex & Aetiology & Signs \&Symptoms & Treatment & FuP & Outcomes \\
\hline Elwir et al. [62] & 2015 & 54 & $\mathrm{~F}$ & $\begin{array}{l}\text { Congenital AVF } \\
\text { (HHT) }\end{array}$ & $\begin{array}{l}\text { Shortness of breath and fluid } \\
\text { overload, A-V shunt in the liver }\end{array}$ & $\begin{array}{l}\text { Liver transplantation } \\
\text { (Refractory to optimal } \\
\text { medical therapy, diuretic/ } \\
\text { anti-angiogenesis } \\
\text { [Bevacizumab]) }\end{array}$ & 2 months & $\begin{array}{c}\text { Cardiac output ( } 8.65 \text { to } 10 \mathrm{~L} / \\
\mathrm{min}), \text { cardiac index }(3.87 \text { to } 4.5 \\
\mathrm{L} / \mathrm{min} / \mathrm{m}^{2} \text { ) all cardiac symptoms } \\
\text { resolved. }\end{array}$ \\
\hline Singh et al. [63] & 2015 & 61 & M & $\begin{array}{l}\text { Iatrogenic iliac } \\
\quad \text { fistula }\end{array}$ & $\begin{array}{l}\text { History of hypertension, CHF } \\
\text { and CAD, jugular venous } \\
\text { distension, pansystolic murmur } \\
\text { at the apex, and bilateral pedal } \\
\text { oedema, mild cardiomegaly }\end{array}$ & Endovascular closure & $\begin{array}{c}\text { End of } \\
\text { procedure }\end{array}$ & $\begin{array}{c}\text { Cardiac output and cardiac index } \\
\text { normalized and patient remained } \\
\text { stable }\end{array}$ \\
\hline Goh et al. [64] & 2016 & 80 & M & Renal disease & Severe bilateral arm swelling. & Surgical removal of AVF & 3 days & Resolution of cardiac symptoms \\
\hline $\begin{array}{l}\text { Muller-Edenborn et } \\
\text { al. [65] }\end{array}$ & 2016 & 74 & & $\begin{array}{c}\text { Post traumatic } \\
\text { AVF (after cardiac } \\
\text { pacemaker) }\end{array}$ & $\begin{array}{l}\text { Exercise intolerance with } \\
\text { dyspnoea }\end{array}$ & $\begin{array}{l}\text { Surgical - implantation of } \\
\text { stent graft }\end{array}$ & 3 months & $\begin{array}{l}\text { Significant improvement in } \\
\text { function capacity but later } \\
\text { experienced non-ST-segment } \\
\text { elevation, myocardial infarction } \\
\text { stenting of right coronary artery }\end{array}$ \\
\hline Park et al. [66] & 2016 & 36 & M & Iatrogenic AVF & $\begin{array}{l}\text { Progressive exertional dyspnoea } \\
\text { over months, and jugular venous } \\
\text { distension, lung crepitations, } \\
\text { femoral bruit, and pitting pedal } \\
\text { oedema }\end{array}$ & $\begin{array}{c}\text { Endovascular sealing with a } \\
\text { bifurcated stent graft }\end{array}$ & 8 weeks & $\begin{array}{l}\text { Resolution of exertional } \\
\text { dyspnoea and orthopnoea, } \\
\text { dilated heart chambers, IVC } \\
\text { diameter and decrease in } \\
\text { pulmonary pressures }\end{array}$ \\
\hline Palleschi et al. [67] & 2017 & 84 & $\mathrm{~F}$ & Paget's disease & $\begin{array}{l}\text { Severe pain in multiple vertebral } \\
\text { fractures, left ilio and ischio- } \\
\text { pubic branches fracture and } \\
\text { sacral fracture, dyspnoea, } \\
\text { pulmonary oedema }\end{array}$ & $\begin{array}{l}\text { oral bisphosphonates } \\
\text { (residronate) }\end{array}$ & 3 months & $\begin{array}{l}\text { Resolution of severe pain, } \\
\text { regression of symptoms, slight } \\
\text { limitation of normal physical } \\
\text { activity, }\end{array}$ \\
\hline Shah et al. [68] & 2017 & $\begin{array}{l}\text { 2-day } \\
\text { premature } \\
\text { infant }\end{array}$ & $\mathrm{F}$ & $\begin{array}{l}\text { Scalp congenital } \\
\text { haemangiomas }\end{array}$ & $\begin{array}{l}\text { Extracranial mass, cardiomegaly, } \\
\text { haematuria, coagulopathy, } \\
\text { anaemia, and hypotension, and } \\
\text { signs of end-organ injury, RV and } \\
\text { common carotid artery dilation }\end{array}$ & Endovascular therapy & 2 months & $\begin{array}{l}\text { Hypotension, acidosis, oliguria, } \\
\text { and coagulopathy resolved, } \\
\text { hemodynamic stability, right } \\
\text { parietal mass regressed }\end{array}$ \\
\hline
\end{tabular}

AVF: Arteriovenous Fistula; CAD: Coronary Artery Disease; CHF: Congestive Heart Failure; FuP: Follow-up Period; HHT: Hereditary Haemorrhagic Telangiectasia

total knee replacement therapy, nephrectomy or cardiac pacemaker implantation $[50,51,56,57,60,63,65,66]$, congenital AVF [52,61,62,67], renal failure [48,55,58,64] and multiple myeloma [53]. Diseases with vasodilation features included hyperthyroidism [59] and pregnancy [49,54] (Table 5).

\section{Differential diagnosis}

The basis of differential diagnosis of high-output HF in all the 23 cases is a combination of clinical evidence of HF (demonstrated abnormalities in cardiac function and/or structure), high cardiac output state and underlying aetiology consistent with high-output state. Clinical evidence of HF include typical cardiac symptoms of HF, physical signs and imaging findings. The common cardiac symptoms included progressive exertional dyspnoea, lower extremities oedema, pulmonary oedema, fatigue and general weakness while the common sings in physical examination included elevated jugular venous pressure, hepatojugular reflux, third heart sound (gallop rhythm), laterally displaced apical impulse and pulmonary crepitation [48-51,5362,65-68]. Others are tachycardia, cardiomegaly, and cardiac murmur $[48,51,53,59,63,68]$. Cardiac symptoms and signs raise the suspicion of HF while cardiac imaging confirm the diagnosis of HF. Differential diagnosis is based on high cardiac output or cardiac index and the presence of warm extremities [48,51-53,55,58-63].

\section{Clinical management}

In all the 23 cases, the emphasis on clinical management of highoutput HF is the treatment of the underlying disease while treatment target is to lower/normalize cardiac output, increase systemic vascular resistance and resolve cardiac symptoms. In patients with high-output HF secondary to systemic AVF and cardiac symptoms refractory to maximal medical therapy, treatment focuses on either endovascular or surgical removal of AVF. Endovascular therapy was safe and efficacious in cardiac symptomatic resolution and normalization of cardiac output in high-output HF secondary to iatrogenic AVF $[63,66]$ and scalp congenital haemangiomas [68]. In cases where fistulas were too large for endovascular closure, surgical removal was effective. Surgical removal, ligation or repair was effective through liver transplantation in patients with hepatic disease $[48,62]$, nephrectomy in patients with kidney diseases or dialysis associated AVF [49,57,64], ligation and surgical repairs in post-traumatic AVF [60], surgical repair following total knee arthroplasty [50] and surgical implantation of stent graft in AVF associated with pacemaker implantation [65]. For patients with high-output HF secondary to disease with vasodilatory pathophysiology, medical treatment is a common option. In addition to resolution of cardiac symptoms, anti-thyroid medications restore euthyroid state in hyperthyroidism patients [59], Metoprolol, furosemide \& spironolactone relief of abdominal pain in pregnancy [54], and oral bisphosphonates in Paget's disease [67]. Diuretic and/ or anti-angiogenesis are not effective in resolving cardiac symptoms in patients with hepatic disease [62] but effective normalizing cardiac output in patients with multiple myeloma and high-output HF [53].

\section{Discussion}

High-output $\mathrm{HF}$ is an uncommon and understudied clinical form of HF. Clinical trial data on important clinical features such as epidemiology, natural history, pathophysiology, diagnosis and treatment are conspicuously lacking. Whereas findings from case reports may provide valuable information to inspire clinical research, the perception of increased risk of bias and the absence of a control group for comparison makes it less useful in informing reliable clinical decision-making. In the present systematic analysis, 23 cases from 21 case reports suggest that differential diagnosis of highoutput HF requires the demonstration of three main features. (a) The demonstration of cardiac symptoms and physical signs of HF; (b) the 
demonstration of high-output state such as high cardiac output or cardiac index; and (c) the detection of underlying aetiology capable of producing high-output state. The findings also suggests that while short term management of decompensated state of high-output $\mathrm{HF}$ remains a challenge, long-term clinical management is treatment of the underlying cause of high-output state. While non-medical procedures mainly surgical and endovascular therapies are common for highoutput patients with arteriovenous-shunting pathologies, medical procedures are common in vasodilation pathologies such as pregnancy, hyperthyroidism and obesity.

The present findings from case reports on differential diagnosis of high-output HF are consistent with previous review articles [3-5,9]. In these review articles, while high- and low-output HF may present with similar cardiac symptoms and physical signs of HF, the main differentiating features of high-output HF include high cardiac output/ index, warm peripheries, preserved ejection fraction and aetiologies consistent with high-output state. Although several underlying aetiologies have been described in these reviews [3-5,9] as well as in the Reddy et al. [10] clinical trial identifying obesity as the most common cause $(31 \%)$, case reports do not provide an accurate picture since a majority have investigated high-output HF with arteriovenousshunting pathologies. As a result, case reports seem to grossly under-present high-output failure due to vasodilatory pathologies undermining ability to analyse disease prevalence by aetiologies.

The evidence on the treatment of high-output HF is limited and fragmented. In the present findings, the safety and efficacy of treatment of underlying aetiologies in normalizing cardiac symptoms and resolving cardiac symptoms was demonstrated. On the other hand, no clear short-term medical therapies on the management of patients with high-output $\mathrm{HF}$ in a decompensated state emerged. Therapies such as dietary restriction of salt and water, diuretics and vasoconstrictor adrenergic drugs such as noradrenaline, ephedrine, metaraminol and phenylephrine have been proposed for short-term use for hemodynamic stabilize, evidence on their safety and efficacy in both short- and long-term are yet to be demonstrated in clinical trials [5]. The present findings suggests the need large scale and longterm clinical trials on treatment of high-output HF to determine the safety and efficacy of HF medication and therapies on different underlying aetiologies. Such clinical trials will be valuable to develop focused treatment strategies and even guidelines for effective clinical management of decompensated HF in high-output HF.

\section{Conclusion}

High-output HF describes an unusual cause of cardiac failure associated with increased mortality. Its epidemiology remains unknown largely because it lacks precise diagnostic guidelines and its incidence may be related to several different underlying diseases responsible for the high-output state. Its aetiology is characterized into diseases causing peripheral vasodilation such as morbid obesity, hyperthyroidism, severe anaemia, sepsis, cardiac beriberi, pregnancy and liver disease, or disease causing arteriovenous shunting such as systemic arteriovenous fistula, multiple small arteriovenous shunts, multiple myeloma and skeletal disease. The pathophysiology hallmark is excessively depressed systemic vascular resistance and heightened metabolic demand leading to the activation of neurohormones mainly renin-angiotensin-aldosteronesystem and antidiuretic, and subsequent salt and water retention despite a hyperdynamic state. Diagnosis is through history and physical examination along with appropriate laboratory and cardiac imaging. Features of differential diagnosis are warm peripheries, preserved LV function, increased cardiac output/index and increased mixed venous oxygen saturation. Predictors of prognosis are the type of underlying disease and the degree of vasodilation. The condition lacks clinical trial data and in the absence of a remediable cause, therapeutic options are limited and many of the accepted therapies for low-output HF are contra-indicated. Treatment usually includes salt and water restriction, judicious use of diuretics and correcting the cause of the high-output state or low systemic vascular resistance.

\section{References}

1. Inamdar A, Inamdar A (2016) Heart failure diagnosis, management and utilization. $J$ Clin Med 5: 62. [Crossref]

2. McMurray JJ, Adamopoulos S, Anker SD, Auricchio A, Bohm M, et al. (2012) ESC Guidelines for the diagnosis and treatment of acute and chronic heart failure 2012. Eur $J$ Heart Fail 14: 803-869. [Crossref]

3. Singh S, Sharma S (2018) High-Output Cardiac Failure. InStatPearls [Internet] StatPearls Publishing [Crossref]

4. Anand IS, Florea VG (2001) High output cardiac failure. Curr Treat Options Cardiovasc Med 3: 151-159. [Crossref]

5. Mehta PA, Dubrey SW (2009) High output heart failure. QJM: Int J Med 102: 235-241 [Crossref]

6. Roger VL (2013) Epidemiology of heart failure. Circ Res 113: 646-659. [Crossref]

7. Roger VL, Go AS, Lloyd-Jones DM, Adams RJ, Berry JD et al. (2011) Heart disease and stroke statistics-2011 update: a report from the American Heart Association. Circulation 123: e18-209. [Crossref]

8. Swedberg K, Cleland J, Dargie H, Drexler H, Follath F et al. (2005) Guidelines for the diagnosis and treatment of chronic heart failure: executive summary (update 2005) The Task Force for the Diagnosis and Treatment of Chronic Heart Failure of the European Society of Cardiology. Eur Heart J 26: 1115-1140. [Crossref]

9. Dharmendra J, Subramanian G, Aviraj C, Balaji V (2016) High-Output Heart Failure: Diagnosis and Management 501-507. [Crossref]

10. Reddy YN, Melenovsky V, Redfield MM, Nishimura RA, Borlaug BA (2016) Highoutput heart failure: a 15-year experience. J Am Coll Cardiol 68: 473-482. [Crossref]

11. Vargas-Uricoechea H, Bonelo-Perdomo A, Sierra-Torres CH (2014) Effects of thyroid hormones on the heart. Clínica e Investigación en Arteriosclerosis 26: 296-309. [Crossref]

12. Ho WJ, Chen ST, Tsay PK, Wang CL, Hsu TS et al. (2007) Enhancement of endotheliumdependent flow-mediated vasodilation in hyperthyroidism. Clin Endocrinol 67: 505511. [Crossref]

13. Biondi B (2012) Heart failure and thyroid dysfunction. Eur J Endocrinol 6: EJE-12. [Crossref]

14. Brewster WR, Isaacs JP, Osgood PF, King TL (1956) The hemodynamic and metabolic interrelationships in the activity of epinephrine, norepinephrine and the thyroid hormones. Circulation 13: 1-20. [Crossref]

15. Dalan R, Leow M (2007) Cardiovascular collapse associated with beta blockade in thyroid storm. Exp Clin Endocrinol Diabetes 115: 392-396. [Crossref]

16. Parrillo JE (1993) Pathogenetic mechanisms of septic shock. N Engl J Med 328: 14711477. [Crossref]

17. Rotheram Jr EB (1989) High output congestive heart failure in septic shock. Chest 95 1367-1368. [Crossref]

18. Bone RC, Grodzin CJ, Balk RA (1997) Sepsis: a new hypothesis for pathogenesis of the disease process. Chest 112: 235-244. [Crossref]

19. Akbarian M, Yankopoulos NA, Abelmann WH (1966) Hemodynamic studies in beriberi heart disease. Am J Med 41: 197-212. [Crossref]

20. Ayzenberg O, Silber MH, Bortz D (1985) Beriberi heart disease. A case report describing the haemodynamic features. S Afr Med J 68: 263-265. [Crossref]

21. Anand IS, Chandrashekhar Y, Ferrari R, Poole-Wilson PA, Harris PC (1993) Pathogenesis of oedema in chronic severe anaemia: studies of body water and sodium, renal function, haemodynamic variables, and plasma hormones. Heart 70: 357-362. [Crossref]

22. Ni Z, Morcos S, Vaziri ND (1997) Up-regulation of renal and vascular nitric oxide synthase in iron-deficiency anaemia. Kidney int 52: 195-201. [Crossref]

23. Fowler NO, Holmes JC (1975) Blood viscosity and cardiac output in acute experimenta anaemia. J Appl Physiol 39: 453-456. [Crossref] 
24. Alpert MA (2001) Obesity cardiomyopathy: pathophysiology and evolution of the clinical syndrome. Am J Med 321: 225-236. [Crossref]

25. Galinier M, Pathak A, Roncalli J, Massabuau P (2005) Obesity and cardiac failure. Arch Mal Coeur Vaiss 98: 39-45. [Crossref]

26. Contaldo F, Pasanisi F, Finelli C (2002) Obesity, heart failure and sudden death. Nutr Metab Cardiovasc Dis 12: 190-197. [Crossref]

27. Kenchaiah S, Evans JC, Levy D, Wilson PW, Benjamin EJ et al. (2002) Obesity and the risk of heart failure. $N$ Engl $J$ Med 347: 305-313. [Crossref]

28. Bergrem H, Flatmark A, Simonsen S (1978) Dialysis fistulas and cardiac failure. Acta Medica Scandinavica 204: 191-193. [Crossref]

29. Anderson CB, Codd JR, Graff RA, Groce MA, Harter HR et al. (1976) Cardiac failure and upper extremity arteriovenous dialysis fistulas: case reports and a review of the literature. Archives of internal medicine 136: 292-297. [Crossref]

30. Heistad DD, Abboud FM, Schmid PG, Mark AL, Wilson WR (1975) Regulation of blood flow in Paget's disease of bone. J Clin Invest 55: 69-74. [Crossref]

31. Henley JW, Croxson RS, Ibbertson HK (1979) The cardiovascular system in Paget's disease of bone and the response to therapy with calcitonin and diphosphonate. Aust $N$ Z J Med 9: 390-397. [Crossref]

32. Arnalich F, Plaza I, Sobrino JA, Oliver J, Barbado J et al. (1984) Cardiac size and function in Paget's disease of bone. Int J Cardiol 5: 491-505. [Crossref]

33. McBride W, Jackman Jr JD, Gammon RS, Willerson JT (1988) High-output cardiac failure in patients with multiple myeloma. $N$ Engl J Med 319:1651-1653. [Crossref]

34. Inanir S, Haznedar R, Atavci S, Unlu M (1998) Arteriovenous shunting in patients with multiple myeloma and high-output failure. J Nucl Med 39: 1. [Crossref]

35. Cohn JN, Levine TB, Francis GS, Goldsmith S (1981) Neurohumoral control mechanisms in congestive heart failure. Am Heart $J$ 102: 509-514. [Crossref]

36. Schrier RW (1988) Pathogenesis of sodium and water retention in high-output and lowoutput cardiac failure, nephrotic syndrome, cirrhosis, and pregnancy. $N$ Engl J Med 319: 1127-1134. [Crossref]

37. Anand IS (2016) High-output heart failure revisited. J Am Coll Cardiol 68: 483-486 [Crossref]

38. Yancy CW, Jessup M, Bozkurt B, Butler J, Casey DE, et al. (2013) 2013 ACCF/AHA guideline for the management of heart failure: a report of the American College of Cardiology Foundation/American Heart Association Task Force on Practice Guidelines. $J$ Am Coll Cardiol 62: e147-239. [Crossref]

39. Ponikowski P, Voors AA, Anker SD, Bueno H, Cleland JG, et al. (2016) 2016 ESC Guidelines for the diagnosis and treatment of acute and chronic heart failure: The Task Force for the diagnosis and treatment of acute and chronic heart failure of the European Society of Cardiology (ESC) Developed with the special contribution of the Heart Failure Association (HFA) of the ESC. Eur Heart J 37: 2129-2200. [Crossref]

40. Mangini S, Silveira FS, Silva CP, Grativvol PS, Seguro LF et al. (2008) Decompensated heart failure in the emergency department of a cardiology hospital. Arquivos brasileiros de cardiologia 90: 433-440. [Crossref]

41. Cardinale L, Priola AM, Moretti F, Volpicelli G (2014) Effectiveness of chest radiography, lung ultrasound and thoracic computed tomography in the diagnosis of congestive heart failure. World J Radiol 6: 230-237. [Crossref]

42. Dupuis-Girod S, Ginon I, Saurin JC, Marion D, Guillot E et al. (2012) Bevacizumab in patients with hereditary hemorrhagic telangiectasia and severe hepatic vascular malformations and high cardiac output. JAMA 307: 948-955. [Crossref]

43. Murad MH, Sultan S, Haffar S, Bazerbachi F (2018) Methodological quality and synthesis of case series and case reports. BMJ Evid Based Med 2: ebmed-2017. [Crossref]

44. Burns PB, Rohrich RJ, Chung KC (2001) The levels of evidence and their role in evidence-based medicine. Plastic and reconstructive surgery 128: 305. [Crossref]

45. Gupta N, Asi N, Farah W, Almasri J, Barrionuevo P, et al. (2016) Clinical Features and Management of Non-HIV-Related Lipodystrophy in Children: A Systematic Review. $J$ Clin Endocrinol Metab 102: 363-374. [Crossref]

46. Martyn C. Case reports, case series and systematic reviews. QJM: An International Journal of Medicine 95: 197-198. [Crossref]

47. Murad MH, Rizvi AZ, Malgor R, Carey J, Alkatib AA, et al. (2011) Comparative effectiveness of the treatments for thoracic aortic transaction. J Vasc Surg 53: 193-199. [Crossref]

48. Braverman AC, Steiner MA, Picus D, White H (1995) High-output congestive heart failure following transjugular intrahepatic portal-systemic shunting. Chest 107: 14671469. [Crossref]
49. Korn TS, Thurston JM, Sherry CS, Kawalsky DL (1998) High-output heart failure due to a renal arteriovenous fistula in a pregnant woman with suspected preeclampsia. Mayo Clinic Proceedings, 73: 888-892. [Crossref]

50. Manghat NE, Broadley AJ, Puckett MA, Isaacs J, Currie I (2003) High Output Cardiac Failure Caused by Popliteal Pseudoaneurysm and Arteriovenous Fistula Following Total Knee Replacement Simulating Severe Aortic Stenosis. EJVES Extra 6: 10-14. [Crossref]

51. Ozaki K, Oda H, Hatada K, Sakai K, Takahashi K etal. (2003) Highly vascular pelvic tumor causing high-output heart failure because of massive arteriovenous shunting. Circulation journal 67: 554-555. [Crossref]

52. Mitchell A, Adams LA, MacQuillan G, Tibballs J, vanden Driesen R et al. (2008) Bevacizumab reverses need for liver transplantation in hereditary haemorrhagic telangiectasia. Liver transplantation 14: 210-213. [Crossref]

53. Robin J, Fintel B, Pikovskaya O, Davidson C, Cilley J et al. (2008) Multiple myeloma presenting with high-output heart failure and improving with anti-angiogenesis therapy: two case reports and a review of the literature. Int $J$ Med Case Reports 2 : 229. [Crossref]

54. Goussous T, Haynes A, Najarian K, Daccarett M, David S (2009). Hereditary hemorrhagic telangiectasia presenting as high output cardiac failure during pregnancy. Cardiology research and practice 2009. [Crossref]

55. Khreiss M, Haddad FF, Musallam KM, Medawar W, Daouk M et al. (2009) Highoutput cardiac failure secondary to a large arteriovenous fistula: a persistent threat to the dialysis and kidney transplant patient. NDT plus 2: 147-148. [Crossref]

56. Turgutalp K, Horoz M, Ozcan T, Yildiz A, Oguz EG et al. (2011) Development of highoutput heart failure after correction of central venous occlusion: a case report. Renal failure 33: 833-836. [Crossref]

57. Khan I, Saxena GN, Keshwani P, Srivastava S, Singh S et al. (2013) Irreversible Thyrotoxic Dilated Cardiomyopathy: Case Reports and Review of Literature. Indian Journal of Clinical Practice 23: 795-797. [Crossref]

58. Rymer JA, Anderson LL, Posenau JT, Jones WS (2013) Remote stab wound resulting in $\mathrm{AV}$ fistula and high-output heart failure. Case reports in cardiology [Crossref]

59. Chen J, Liu M, Ke J, Shang B, Zhu Z et al. (2014) An unusual cause of high-output heart failure: renal arteriovenous fistula after nephrectomy. Circulation: Heart Failure 7: 378-379. [Crossref]

60. Hayek S, Kung R, Barb I, Master V, Al S, Clements S (2014) Digging deep: high output heart failure in renal cell carcinoma. Am J Med 127: 22-24. [Crossref]

61. Singh G, Adhami T, Alkhouri N (2014) Hereditary hemorrhagic telangiectasia with liver vascular malformation presenting with high-output heart failure. $A C G$ case reports journal 2: 16-17. [Crossref]

62. Elwir S, Martin CM, Chinnakotla S, Reding M, Lake J, et al. (2015) Liver Transplantation for High Output Heart Failure Secondary to HHT: A Case Report and Review of the Literature. J Gastrointest Dig Syst 5:331. [Crossref]

63. Singh S, Singh S, Jyothimallika J, Lynch TJ (2015) May-Thurner syndrome: High output cardiac failure as a result of iatrogenic iliac fistula. World Journal of Clinical Cases: WJCC 3: 318. [Crossref]

64. Goh MA, Ali JM, Lagaac R, Barlow AD, Pettigrew GJ (2016) High output cardiac failure following formation of an axillo-iliac arteriovenous graft for haemodialysis. The journal of vascular access 17: 7-9. [Crossref]

65. Muller-Edenborn B, Allgeier J, Hartmann R, Zeller T, Arentz T (2016) High-output heart failure due to subclavian vessel fistula as a late complication following implantation of a biventricular pacemaker. Heart Rhythm case reports 2: 425. [Crossref]

66. Park T, Park SH, Arora A (2016) Delayed High Output Heart Failure due to Arteriovenous Fistula Complicated with Herniated Disc Surgery. Journal of Korean medical science 31: 2051-2053. [Crossref]

67. Palleschi L, Nunziata E (2017) Severe congestive heart failure in elderly patient with Paget's disease. Geriatric Care 3. [Crossref]

68. Shah SS, Snelling BM, Sur S, Ramnath AR, Bandstra ES et al. (2017) Scalp congenita hemangioma with associated high-output cardiac failure in a premature infant: Case report and review of literature. Interv Neuroradiol 23: 102-106. [Crossref]

Copyright: (C2019 Albakri A. This is an open-access article distributed under the terms of the Creative Commons Attribution License, which permits unrestricted use, distribution, and reproduction in any medium, provided the original author and source are credited. 